\title{
Characterization of Biomass Bottom Ash from an Industrial Scale Fixed-Bed Boiler by Fractionation
}

\author{
Adrian K. James ${ }^{1}$, Ronald W. Thring ${ }^{1}$, P. Michael Rutherford ${ }^{1} \&$ Steve S. Helle ${ }^{1}$ \\ ${ }^{1}$ Environmental Science \& Engineering, University of Northern British Columbia, 3333 University Way, Prince \\ George, Canada \\ Correspondence: Ronald W. Thring, Environmental Science \& Engineering, University of Northern British \\ Columbia, 3333 University Way, Prince George, BC V2N 4Z9, Canada. Tel: 1-250-960-5804. E-mail: \\ thring@unbc.ca
}

Received: May 13, 2013 Accepted: June 18, 2013 Online Published: July 26, 2013

doi:10.5539/eer.v3n2p21 URL: http://dx.doi.org/10.5539/eer.v3n2p21

\begin{abstract}
It is expected that increasing amounts of energy will be generated from the direct combustion of biomass residues. However, biomass combustion processes are known to produce large amounts of bottom ash, resulting in ash storage and disposal problems. The presence of unburned carbon in some bottom ash suggests its potential for beneficial uses, such as an energy source. This comparative study characterizes two bottom ash samples obtained from an industrial scale fixed-bed boiler. The physical and chemical properties of each bottom ash, as well as their respective particle fractions obtained by sieving, are analyzed and discussed. Analyses included proximate and ultimate analysis, Brunauer-Emmett-Teller (BET) surface area, thermogravimetric analysis (TGA) and bulk density. The percent fixed carbon in the samples was $30 \%$ and $50 \%$. The higher heating value (HHV) ranged from $5-25 \mathrm{MJ} / \mathrm{kg}$ for the ash samples when characterized within fractions. The boiler ash showed that $68 \%$ or more of the energy could be recovered in fractions $\geq 425 \mu \mathrm{m}$ for high carbon ash. Low carbon fractions of ash have four times the bulk density compared to the high carbon fractions. By reburning the larger fractions, ash volumes can be decreased by over $50 \%$.
\end{abstract}

Keywords: bottom ash, fixed carbon, heating value, bulk density, ash, energy content

\section{Introduction}

Increased use of bioenergy has significantly increased ash generation in many countries. Large-scale utilisation of wood and wood residues for district heating plants, process heating plants and combined heat and power plants has resulted in large volumes of ash production. It is projected that by 2020 , the thermal application of biomass in European countries will result in an annual ash production of approximately 15.5 million tons per year (Obernberger \& Supancic, 2009).

Ash formed during biomass combustion can be divided into bottom ash and fly ash (Picco, 2010). Bottom ash is the fraction produced on the grate in the primary combustion chamber. While many studies have investigated fly ash, bottom ash usually accounts for 60 to $90 \%$ of the total ash generated (Obernberger \& Supancic, 2009).

A number of barriers to the utilization of wood ash have been identified, including heavy metal concentrations and the presence of organic pollutants (Obernberger \& Supancic, 2009). High amounts of organic carbon in the ash indicate incomplete combustion of biomass, which suggests inefficient fuel use (Picco, 2010; Demirbas, 2005). The presence of carbon in ash limits its application in forest soils since carbon dilutes the liming and fertilization effects and also restricts the hardening of the ash (Demirbas, 2005; Sarenbo, 2009). Ash hardening is used to improve handling, reduce dust and to decrease the ash dissolution rate. Unburned matter, as indicated by high carbon content, increases ash volumes and results in higher handling, transportation, disposal and spreading costs (Demirbas, 2005; Gomez-Barea, Vilches, Campoy, \& Fernandez-Pereira, 2009). For many environmental applications, it has been shown that the carbon content should be below $5 \mathrm{wt} \%$ (dry basis) (Van Loo \& Kopejan, 2008). In addition, the high combustibility of char, restricts the application of high carbon ash to some lands due to increased forest fire risk (Dimitrakopoulous, 2001). 
According to Emilsson, a high content of uncombusted material in ash leads to difficulty in ash hardening for use in construction materials and suggests that high charcoal content in the ash can be recombusted (Emilsson, 2006). High content of uncombusted material also poses problems when used in cement compositions.

The relationship between bulk density and the presence of unburnt carbon in ash is important when considering ash transport and storage. High bulk densities may reduce ash volumes, thus decreasing the need for additional storage space and reducing transportation costs. Bulk density decreases with the fineness of the ash fraction (Van Loo \& Kopejan, 2008). The authors reported that ash from straw and cereal combustion showed low density due to its specific chemical matrix, containing more salts and less minerals when compared to wood ash. The bulk density of bottom ash from bark combustion and woodchip combustion, both from a moving grate underfeed stoker, had densities of $950 \mathrm{~kg} / \mathrm{m}^{3}$ (Pels, de Nie, \& Kiel, n.d). On the other hand, the bulk density of bottom ash from sawdust combustion (from an underfeed stroker) was $650 \mathrm{~kg} / \mathrm{m}^{3}$. Thus, fuel type may influence the bulk density of the produced ash.

While improving combustion system efficiency is integral to reducing the carbon content of bottom ash, identifying effective recycling methods are also essential in dealing with high carbon ash. The unburned carbon content in bottom ash varies amongst combustion systems. Short residence time (Duan, Liu, Chen, \& Zhao, 2012) and high ash content are considered as major factors for the incomplete burnout of char. High ash content may result in an ash layer covering the char and preventing the free movement of gases to the core of the char during combustion. State-of-the-art fluidized bed combustion systems have combustion efficiencies of over $95 \%$ irrespective of ash content (Saidur, Abdelaziz, Demirbas, Hossain, \& Mekhilef, 2011). In these systems, the only ash fraction that may contain a high carbon content is the coarse fly ash fraction (as precipitated in cyclones) which is reintroduced into the combustion chamber.

A possible use of ash, depending on the carbon content, is as a fuel (Gomez-Barea et al., 2009). Preliminary research on this idea has been carried out predominantly on fly ash (Duan et al., 2012). Gasification of high-carbon fly ash has been investigated and the resulting ash shows positive results in the production of C-fix blocks, a concrete-like material that uses a heavy petroleum residue as a binder (Pels, de Nie, \& Kiel, n.d). The high carbon content in some forms of ash could also make it useful as a fuel after briquetting or if pelletized (Batra, Urbonaite, \& Svensson, 2008; Cetin, Moghtaderi, Gupta, \& Well, 2004). Combustion of the high carbon ash presents a number of operational problems. Related problems include corrosion (Khan, Jong, Jansens, \& Spliethoff, 2009) and scouring. Based on the design of the boilers, the ash may be carried with the flue gas through the boiler tubes (Saidur et al., 2011). The variability in particle sizes as the feedstock becomes more burnt-out also causes inherent problems in fixed bed systems. Fixed bed systems usually require a feedstock that is as uniformed as possible so as to avoid channeling (Ryu, Yang, Khor, Yates, Sharifi, \& Swithenbank, 2006; Warnecke, 2000).

This study investigates the high carbon bottom ash from fixed bed boilers generated by a large pulp and paper producer in Canada. Large volumes of high carbon ash are produced and are typically sent to landfill due to the low potential economic and environmental benefit for other applications. The costs associated with changing the system to a more recent boiler design are considerably high. If the high carbon fraction can be separated from the low carbon fraction of the ash other applications may become viable. Separation methods for isolating carbon from ash include floatation in a continuous mode and fractionation by sieving (Gomez-Barea et al., 2009). Industrially, carbon separation can be carried out using industrial scale sieve shakers for removal of the coarse carbon rich fraction or by scaling up floatation methods.

The objective of this research is to characterize bottom ash from an industrial scale fixed bed boiler and to identify the ash fractions with potential energy importance. This work examines the physical and chemical properties of the ash and ash fractions. Fractions with high carbon contents are identified and an analysis of the combustion behavior is carried out. The data obtained enhances knowledge about the utilization and storage of woody biomass bottom ash.

\section{Experimental Section}

Wood ash from a Canfor Pulp Limited Partnership pulp mill fixed-bed boiler in Northern British Columbia was used in the study. Boiler feed is hog fuel, a mixture of bark and sawdust primarily derived from pine wood with variable particle sizes. Based on an ultimate analysis, the hog fuel is $49 \% \mathrm{C}$ and $6 \% \mathrm{H}$ on a dry basis. Hog fuel moisture content varies depending on sawmill feedstock, ranging from 25 to $50 \%$; ash content is approximately $2.5 \%$. Typically fixed bed boilers operate within 850 to $1400{ }^{\circ} \mathrm{C}$ (Quaak, Knoef, \& Stassen, 1999). This fixed bed boiler produces approximately $27 \mathrm{MW}$ of power and has a lower grate temperature of $255^{\circ} \mathrm{C}$ with an outlet flue gas temperature of $170{ }^{\circ} \mathrm{C}$. Ash samples, denoted B1 and B2 were collected from the system on November 17, 2010 - B1 and on April 27, 2012 - B2. The boiler has a dry ash removal system, and the ash was sampled 
from the ash bins shortly after removal from the boiler. The samples were separated into different particle fractions as described in section 2.1.

\subsection{Particle Size Distribution}

Approximately $100 \mathrm{~g}$ of "as-received" (original sample obtained from boiler) ash was separated into different size fractions using a stack of five sieves $(2000 \mu \mathrm{m}, 850 \mu \mathrm{m}, 425 \mu \mathrm{m}, 250 \mu \mathrm{m}, 150 \mu \mathrm{m})$ arranged in decreasing diameter openings (Herrman \& Baker, 2002). The ash was poured on the top sieve (largest opening), which was then covered; the sieve stack was placed on an automatic shaker for 15 minutes after which the stack was removed. Each sieve with the retained material was gently tapped on the sides before being removed from the stack and weighed. Retained ash was removed and stored, while the sieve trays were thoroughly cleaned and reweighed to obtain the mass of ash retained on each tray. The analyses were repeated twice and an average value calculated and reported.

The following retained fractions were used for subsequent analyses:

$\mathrm{AR}=$ as-received wood-ash,

$\geq 2000 \mu \mathrm{m}$,

$\geq 850 \mu \mathrm{m}$ and $<2000 \mu \mathrm{m}$,

$\geq 425 \mu \mathrm{m}$ and $<850 \mu \mathrm{m}$,

$\geq 250 \mu \mathrm{m}$ and $<425 \mu \mathrm{m}$,

$\geq 150 \mu \mathrm{m}$ and less than $250 \mu \mathrm{m}$

$<150 \mu \mathrm{m}$.

For convenience, the above fractions will simply be denoted as $2000 \mu \mathrm{m}, 850 \mu \mathrm{m}, 425 \mu \mathrm{m}, 250 \mu \mathrm{m}, 150 \mu \mathrm{m}$ and $<150 \mu \mathrm{m}$.

Each of the retained fractions were weighed and then stored for further analysis.

\subsection{Proximate and Ultimate Analysis of Wood Ash}

The proximate analysis of each sample fraction was carried out according to American Society for Testing and Materials (ASTM) method D1762-84. The fixed carbon (FC), volatile matter (VM) and ash content were determined on a dry basis. Samples were dried for $3 \mathrm{~h}$ at $105^{\circ} \mathrm{C}$ to remove all moisture. VM analyses was carried out at $950{ }^{\circ} \mathrm{C}$ for $7 \mathrm{~min}$ in capped crucibles and then ash content was determined at $550{ }^{\circ} \mathrm{C}$ for $6 \mathrm{~h}$ in open crucibles. The FC was determined by difference as shown in Equation (1). The ash content is defined as the remaining inorganic contents after the complete removal of fixed carbon, volatile matter and moisture. All analyses were performed on three replicates and the averages presented.

$$
F C=100-V M-A s h
$$

where FC, VM and Ash content are wt.\% expressed on a dry basis.

Ultimate analysis of carbon $(\mathrm{C})$, hydrogen $(\mathrm{H})$, nitrogen $(\mathrm{N})$, and sulfur $(\mathrm{S})$ was conducted using a $\mathrm{Costech}^{\mathrm{TM}}$ Elemental Analyzer, ECS 4010 Elemental Combustion System. Reactor conditions were: $1000{ }^{\circ} \mathrm{C}$, helium carrier gas at $105 \mathrm{~mL} / \mathrm{min}$, Gas Chromatography (GC) Column \#051080, SS $5 \mathrm{~mm}$ x $2 \mathrm{~m}$, at $100{ }^{\circ} \mathrm{C}, 450 \mathrm{~L}$ x $18 \mathrm{~mm}$ reaction tube, and HayeSep Q 60/80GC column packing. A Thermal Conductivity Detector was used. Results are presented in wt.\% and on a dry basis.

\subsection{Thermal Analysis}

Thermal characteristics were determined using a TA Instrument TGA-50/50H Shimadzu thermogravimetric analyzer. The analyses were conducted using air at a flow rate of $50 \mathrm{~mL} / \mathrm{min}$, under atmospheric conditions. For each test, approximately $10 \mathrm{mg}$ of the sample was heated from room temperature to $800{ }^{\circ} \mathrm{C}$ at a heating rate of $10{ }^{\circ} \mathrm{C} / \mathrm{min}$. The TGA analysis was done only on B1 sample for the AR portion, $\geq 425 \mu \mathrm{m}$ fraction and $<425 \mu \mathrm{m}$ fraction. The thermogravimetric (TG) plots describe the weight loss of the sample with increasing temperatures while the differential thermogravimetric (DTG) plot illustrates the derivative of sample mass with time at a specific temperature.

\subsection{Surface Area}

Brunauer-Emmett-Teller (BET) surface area measurements were carried out with $\mathrm{N}_{2}$ at $-196{ }^{\circ} \mathrm{C}$ using a single-point Micromeritics FlowSorb 112300 surface area analyzer. The surface area was determined only on char particles that were $\geq 2000 \mu \mathrm{m}$ for both B1 and B2 samples. Particles in this fraction were more 
homogeneous due to the absence of finer ash particles and more char-like particles.

\subsection{Heating Value}

The gross calorific value was determined for each fraction using a Parr Oxygen Bomb with approximately $1 \mathrm{~g}$ of boiler ash. Results were determined in accordance with ASTM D-5865/E711 and were calculated relative to sample weight on an oven dried basis.

\subsection{Bulk Density}

The bulk density for each fraction was determined as follows. Approximately $50 \mathrm{ml}$ of sample was placed into a $100 \mathrm{ml}$ graduated measuring cylinder ( $1 \mathrm{ml}$ divisions). The cylinder was then tapped 6 times on a rubber surface from a height of approximately $1.5 \mathrm{in}$. The mass and volume of the sample were then obtained and used to calculate bulk density. This procedure was repeated three times and an average value obtained for each sample. All bulk density determinations were expressed on a dry basis.

\section{Results and Discussion}

\subsection{Particle Size Distribution of Ash}

Distribution of the particles in the boiler samples are shown in Figure 1. Fractions $\geq 250 \mu \mathrm{m}$ showed a similar distribution for both ash samples. The B2 sample was approximately $10 \%$ higher in mass than B1 for the fractions $250 \mu \mathrm{m}, 425 \mu \mathrm{m}$ and $850 \mu \mathrm{m}$. As the particle sizes became smaller, that is for fractions 150 and $<150$ $\mu \mathrm{m}$, the mass of B1 was higher than B2. For B1, fraction $<150 \mu \mathrm{m}$ accounted for the highest weight with $25 \%$ of the total mass passing through the $150 \mu \mathrm{m}$ sieve. The same fraction for B2 was approximately $20 \%$ lower than B1. The difference in the particle size distributions of the samples is likely associated with the variation in the char contents of the AR samples. As char becomes more combusted, the sample particle sizes will decrease due to an increase in ash formation. Therefore, B2 is expected to have greater carbon content in the AR sample.

\subsection{Results of Proximate Analysis and Ultimate Analysis}

The results of the proximate analysis and ultimate analysis of the wood ash samples are shown in Table 1. Percent volatile matter ranged from 0 to $20 \%$ for all samples. The volatile matter for the samples appeared to slightly increase as particle size decreased. This may be due to an increase in inorganic content such as carbonates and oxides that are usually present in wood ash (Liao, Wu, \& Yan, 2007). Ash content increased with decreasing particle size. Fractions $425 \mu \mathrm{m}$ and higher for B1 and B2 ranged from $\sim 17$ to $34 \%$ ash content, while fractions 250 $\mu \mathrm{m}$ and below ranged from $\sim 60$ to $70 \%$. The ash content in the $425 \mu \mathrm{m}$ fractions of B1 and B2, respectively, were $32 \%$ and $23 \%$ lower when compared to their $250 \mu \mathrm{m}$ fractions. In general, the FC content increased with increasing particle size. B2 showed a gradual increase from 10 to $70 \%$ in FC as particle size increased. For both B1 and B2, fractions $425 \mu \mathrm{m}$ and larger contained $50 \%$ or more FC while fractions $250 \mu \mathrm{m}$ and smaller had $\sim 26 \%$ or less FC. The high FC seen in the larger fractions are a result of incomplete combustion of the sample and the presence of char-like particles.

Table 1. Proximate analysis for fixed bed boiler bottom ash samples (B1 \& B2)

\begin{tabular}{ccccccc}
\hline \multirow{2}{*}{$\begin{array}{c}\text { Particle size } \\
(\boldsymbol{\mu m})\end{array}$} & $\begin{array}{c}\mathbf{F C} \\
(\text { wt.\%) }\end{array}$ & $\begin{array}{c}\text { Vm } \\
(\text { wt.\%) }\end{array}$ & $\begin{array}{c}\text { Ash } \\
(\text { wt.\%) }\end{array}$ & $\begin{array}{c}\text { FC } \\
(\text { wt.\%) }\end{array}$ & $\begin{array}{c}\text { Vm } \\
(\text { wt.\%) }\end{array}$ & $\begin{array}{c}\text { Ash } \\
(\text { wt.\%) }\end{array}$ \\
\hline$<150$ & 13.8 & 19.1 & 67.1 & 10.0 & 19.6 & 70.4 \\
150 & 9.5 & 17.5 & 73.0 & 10.6 & 17.1 & 72.3 \\
250 & 16.0 & 17.4 & 66.6 & 25.3 & 17.4 & 57.4 \\
425 & 51.1 & 14.9 & 34.0 & 51.9 & 13.8 & 34.3 \\
850 & 63.6 & 16.7 & 19.7 & 67.8 & 13.5 & 18.7 \\
2000 & 59.0 & 14.8 & 26.2 & 67.4 & 14.9 & 17.7 \\
AR & 29.3 & 15.9 & 54.8 & 54.0 & 15.8 & 30.2 \\
\hline
\end{tabular}

All results are on a dry weight basis.

$\mathrm{AR}=$ as received (i.e. not separated into particle size fractions). 
Table 2 displays the results of the ultimate analysis, and shows the total $\mathrm{C}, \mathrm{H}$, and $\mathrm{N}$ for each particle fraction. In general, the total $\% \mathrm{C}$ increased with increasing particle size fraction. The weight percent distribution of $\mathrm{C}$ for most samples was greater than those from the proximate analysis (i.e. C greater than FC). This is anticipated since the total carbon includes the organic and inorganic $\mathrm{C}$. All samples had $\mathrm{H}$ concentrations of $1 \%$ or less, and $\mathrm{N}$ concentrations of less than $0.3 \%$. S was below detection limits. These low concentrations of $\mathrm{H}$ are expected since the $\mathrm{H}$ present in the wood is converted to $\mathrm{H}_{2} \mathrm{O}$ during the combustion process. Also, sulphur is usually not present or is only present in small amounts in woody biomass samples unless the soil is very high in sulphur content.

Table 2. Ultimate analysis of fixed-bed boiler bottom ash samples (B1\&B2)

\begin{tabular}{ccccccc}
\hline \multirow{2}{*}{$\begin{array}{c}\text { Particle } \\
\text { size }\end{array}$} & \multicolumn{3}{c}{$\mathrm{B} 1$} & & \multicolumn{3}{c}{$\mathrm{B} 2$} \\
$(\mu \mathrm{m})$ & $\mathrm{C}$ & $\mathrm{H}$ & $\mathrm{N}$ & $\mathrm{C}$ & $\mathrm{H}$ & $\mathrm{N}$ \\
\cline { 2 - 7 } & wt.\% & wt.\% & wt.\% & wt.\% & wt.\% & wt.\% \\
\hline$<150$ & 22.70 & 0.41 & 0.06 & 17.17 & 0.65 & 0.04 \\
150 & 15.99 & 0.27 & 0.04 & 13.85 & 0.56 & 0.03 \\
250 & 13.13 & 0.21 & 0.01 & 21.56 & 0.59 & 0.01 \\
425 & 55.32 & 0.81 & 0.70 & 52.76 & 0.79 & 0.06 \\
850 & 63.92 & 0.98 & 0.06 & 66.41 & 0.71 & 0.18 \\
2000 & 68.15 & 0.76 & 0.12 & 70.73 & 0.53 & 0.25 \\
AR & 38.17 & 0.42 & 0.11 & 51.79 & 0.68 & 0.08 \\
\hline
\end{tabular}

All results are on a dry weight basis.

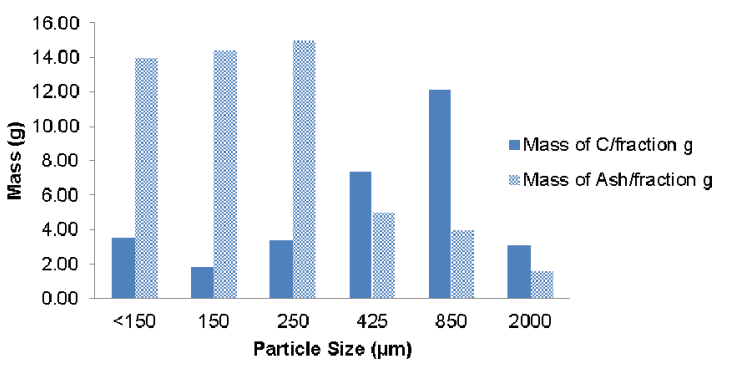

(a)

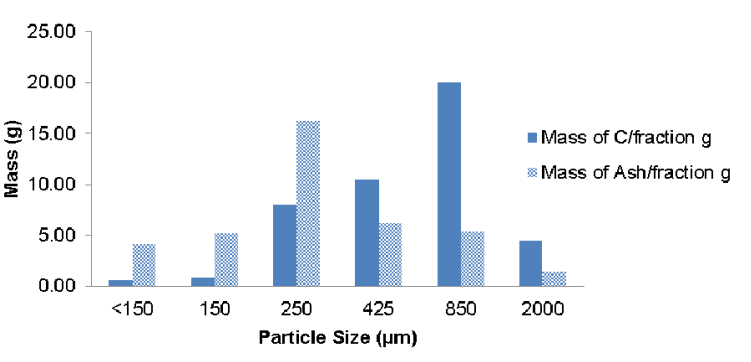

(b)

Figure 2. Distribution of fixed carbon (g) and ash (g) in $100 \mathrm{~g}$ (dry basis) of (a) B1 sample; (b) B2 sample based on particle size fraction distribution

Figure $2 \mathrm{a}$ and $2 \mathrm{~b}$ shows the distribution of fixed carbon (FC) in 100 grams of boiler ash samples B1 and B2. The $850 \mu \mathrm{m}$ fraction for both B1 and B2 were the highest in FC content, $12 \mathrm{~g}$ and $20 \mathrm{~g}$ respectively. Fraction $425 \mu \mathrm{m}$ had the second highest FC contents of 7 and $10 \mathrm{~g}$ respectively. The two boiler ash samples showed a variation in FC distribution. This could be due to a number of factors such as variations in retention time in the reactor, incomplete combustion, temperature variations and fluctuations, moisture content of fuel etc. Also, the moisture content and composition of the biomass feedstock may vary depending on when and where it was sourced. Higher moisture content will reduce the rate of combustion of the fuel. Also, because of the variability in energy demand of the plant, ash may be removed from the grate before complete combustion. This is in addition to the other ash related challenges that occur in the boiler as previously mentioned in the introduction. The $250 \mu \mathrm{m}$ fractions for $\mathrm{B} 1$ and B2 had the highest ash contents of approximately 14 and $26 \mathrm{~g}$. As previously seen in the proximate analysis, fractions $425 \mu \mathrm{m}$ and higher in both boiler samples contain more than $50 \%$ FC. Combined, fractions 425,850 and $2000 \mu \mathrm{m}$ contained $\sim 72 \%$ of the total FC in sample B1. These same fractions accounted for only $\sim 36 \%$ of the total sample mass. For B2, the $425 \mu \mathrm{m}$ and higher fractions contained $\sim 82 \%$ of the total FC and accounted for $59 \%$ of the total mass. The high FC present in boiler ash provides an opportunity for re-burning or reusing its energy. 


\subsection{Thermogravimetric Analysis}

Figure 3 shows the thermal behaviour of the as-received, combined fractions $\geq 425 \mu \mathrm{m}$ and combined fractions $<$ $425 \mu \mathrm{m}$ for boiler ash B1 when heated under air at atmospheric conditions. The results are only shown for B1, however, the results for B2 as-received show similar thermal distributions (not shown). The TGA analyses showed that the mass of the boiler sample decreased as temperature increased. The weight loss occurred in phases which is linked to the removal of specific components of the sample such as water, carbonates, aluminates, silicates, oxides, organic carbon and other components (Zhang, Zhao, \& Jingyu, 2010). All three samples displayed a similar pattern in thermal distribution. The first weight loss was seen between $\sim 25-110{ }^{\circ} \mathrm{C}$ and accounted for the removal of moisture from the sample. A further mass loss was seen up to $\sim 350{ }^{\circ} \mathrm{C}$. This change is generally attributed to the removal of moisture, carbon monoxide, and volatiles such as tars and other organic carbons that may have condensed on the sample (Khan et al., 2009). The most noticeable change in mass of the AR, $\geq 425 \mu \mathrm{m}$ and $<425$ $\mu \mathrm{m}$ fractions was seen between the temperatures 350 to $440{ }^{\circ} \mathrm{C}$ and accounted for $\sim 32,43$ and $14 \%$ mass loss, respectively. This is assumed to be organic carbon (char). Further mass losses occurred between 440 to $610^{\circ} \mathrm{C}$ and between 610 to $670{ }^{\circ} \mathrm{C}$. The decomposition of mineral components such as carbonates $\left(\mathrm{CaCO}_{3}\right)$ and some of the other metal carbonates and oxides present in the sample may occur during this phase. For the range of temperatures studied, the AR, $\geq 425$ and $<425 \mu \mathrm{m}$ fractions lost $\sim 44,56$ and $26 \%$ of initial mass by $800{ }^{\circ} \mathrm{C}$, respectively. Therefore, fractions $\geq 425 \mu \mathrm{m}$ had the highest combustible content. The sample burnout time corresponding to the burnout temperatures, that is, the temperature that shows no further mass loss on the TGA (Idris, Rahman, \& Ismail, 2012; Miranda, Esteban, Rojas, Montero, \& Ruiz, 2008) are shown in Table 3. The fraction $\geq 425 \mu \mathrm{m}$ had a slighter shorter burnout time but was not significantly different from the other two samples under study.

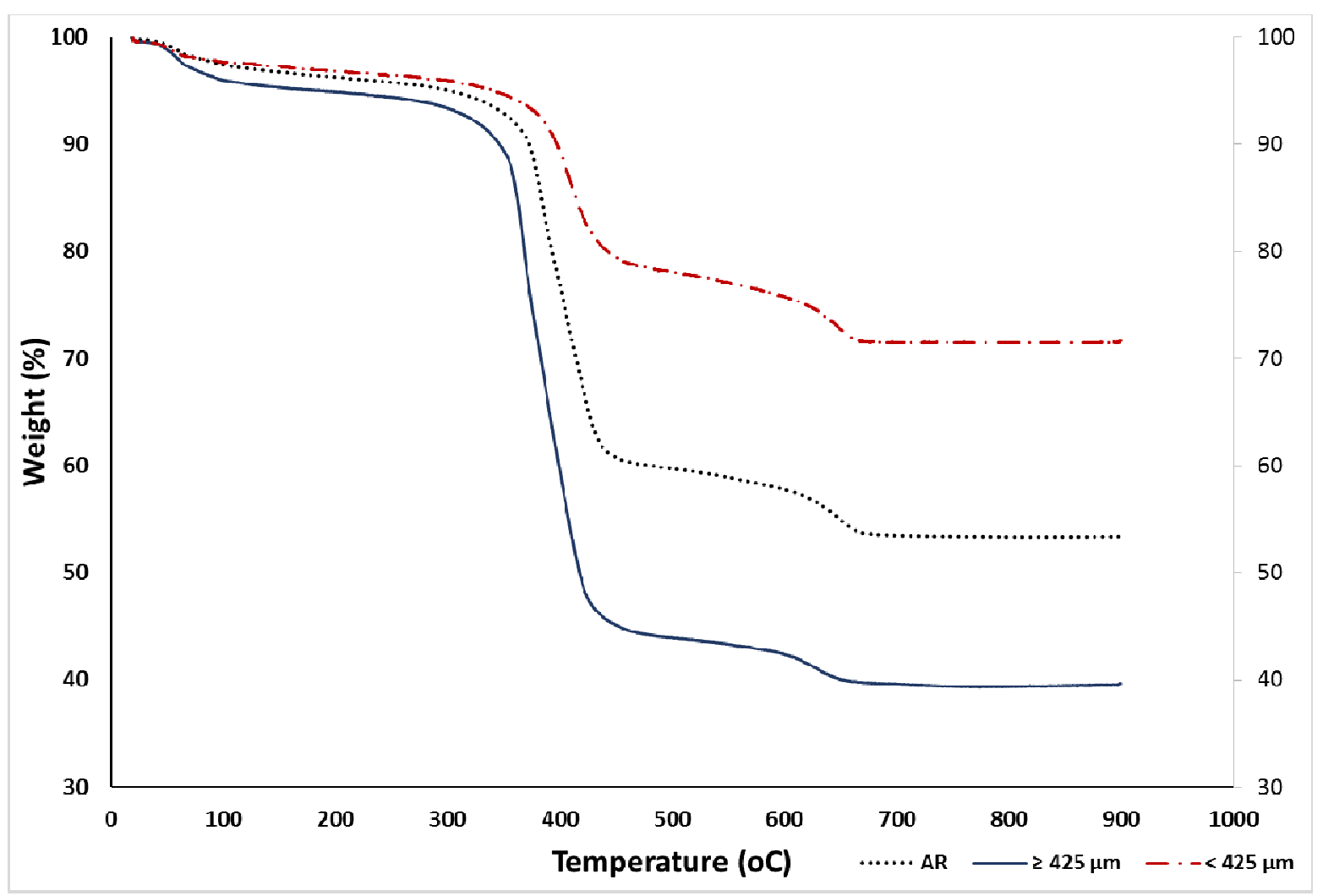

Figure 3. TGA graph of weight change as a function of temperature for B1 boiler ash sample from a fixed bed boiler. Lines displayed represents AR sample, fractions $\geq 425 \mu \mathrm{m}$ and $<425 \mu \mathrm{m}$ 
Table 3. Combustion characteristic of fixed bed boiler bottom ash (B1) samples

\begin{tabular}{|c|c|c|c|c|c|c|}
\hline Sample & $\begin{array}{l}\text { Temperature } \\
\text { range }\left({ }^{\circ} \mathrm{C}\right)\end{array}$ & $\begin{array}{l}\text { Weight } \\
\text { (wt. \%) }\end{array}$ & Loss & $\begin{array}{l}\text { Peak Temperature } \\
\operatorname{Tp}\left({ }^{\circ} \mathrm{C}\right)\end{array}$ & $\begin{array}{l}\text { DTGmax } \\
(\mathrm{mg} / \mathrm{min})\end{array}$ & $\begin{array}{l}\text { Sample burning } \\
\text { time (min) }\end{array}$ \\
\hline \multirow[t]{5}{*}{ AR } & $110-350$ & 4.28 & & & & 35.33 \\
\hline & $350-440$ & 31.98 & & 383 & 1.2082 & \\
\hline & $440-610$ & 3.54 & & & & \\
\hline & $610-670$ & 3.79 & & 649 & 0.2023 & \\
\hline & $670-800$ & 0.36 & & & & \\
\hline \multirow[t]{5}{*}{$\geq 425 \mu \mathrm{m}$} & $110-350$ & 6.49 & & & & 34.23 \\
\hline & $350-440$ & 43.59 & & 362 & 1.3843 & \\
\hline & $440-610$ & 3.71 & & & & \\
\hline & $610-670$ & 2.25 & & 648 & 0.1357 & \\
\hline & $670-800$ & 0.4 & & & & \\
\hline \multirow[t]{5}{*}{$<425 \mu \mathrm{m}$} & $110-350$ & 2.94 & & & & 34.47 \\
\hline & $350-440$ & 14.44 & & 405 & 0.6642 & \\
\hline & $440-610$ & 4.81 & & & & \\
\hline & $610-670$ & 3.83 & & 646 & 0.1815 & \\
\hline & $670-800$ & 0.15 & & & & \\
\hline
\end{tabular}

Results are on a dry basis.

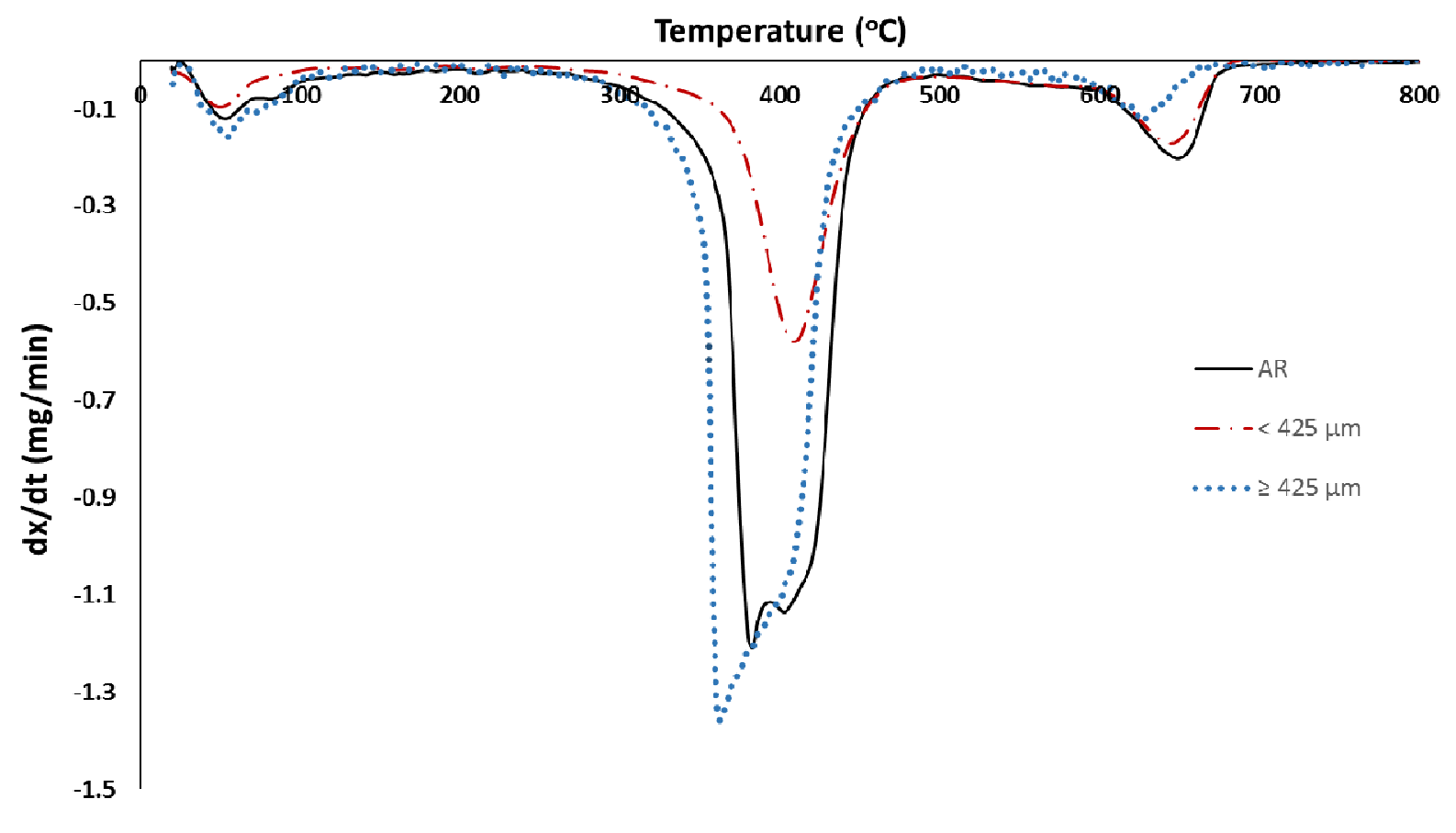

Figure 4. DTGA graph displaying rate of mass loss as a function of temperature for B1 boiler ash sample from a fixed bed boiler. Lines displayed represents AR sample, fractions $\geq 425 \mu \mathrm{m}$ and $<425 \mu \mathrm{m}$

The DTGA analysis in Figure 4 shows two distinct peaks. These peaks are associated with the thermal oxidation of different components in the particles such as carbonized material, heavy organic molecules, condensed tars and inorganic compounds (Miguel, Dominguez, Hemandez, \& Sanz-Perez, 2012). As seen in Table 3, the AR sample, 
fractions $\geq 425$ and $<425 \mu \mathrm{m}$ had the highest rate of mass losses at $\sim 1.2082 \mathrm{mg} / \mathrm{min}$ at $383{ }^{\circ} \mathrm{C}, 1.3843 \mathrm{mg} / \mathrm{min}$ at $362{ }^{\circ} \mathrm{C}$, and $0.6642 \mathrm{mg} / \mathrm{min}$ at $405{ }^{\circ} \mathrm{C}$, respectively. Lignocellulosic samples heated in air typically have well resolved peaks at $\sim 400{ }^{\circ} \mathrm{C}$ (Elder, Kush, \& Hermann, 2011) (Di Blasi, 2009). The fractions containing higher carbon contents were observed to have lower peak temperatures. Peak temperatures determines how easily a fuel is ignited and is defined as the maximum rate of weight loss due to volatilization accompanied by the formation of carbonaceous residue, on the DTGA curve (Idris et al., 2012). Low peak temperatures mean that the fuel is easier to ignite. Since the $\geq 425 \mu \mathrm{m}$ fraction was found to have the highest rate of mass loss at a lower temperature, faster reaction times and lower ignition temperatures could be observed if re-burned, when compared to the other two samples. The samples showed clearly defined thermal phases when heated and oxidized and contained substantial amounts of combustible material, particularly char for the AR sample and particle fractions $\geq 425 \mu \mathrm{m}$.

\subsection{Surface Area}

The $\mathrm{N}_{2}$-BET surface area absorption B1 and B2 ( $\geq 2000 \mu \mathrm{m}$ fraction) were 850 and $770 \mathrm{~m}^{2} / \mathrm{g}$, respectively. The high surface areas obtained are expected for wood ash chars (Link, et al., 2010; Hanaoka, Sakanishi, \& Okumura, 2012; Demirbas, 2005). This may influence the reactivity rate during combustion or gasification processes. A larger available surface area provides more sites for oxygen to bond with carbon (Moulijn \& Kapteijn, 1995) increasing oxidation. It has been reported that wood chars that are produced at higher temperatures have a higher surface area (James, Sabatini, Chiou, Rutherford, Scott, \& Karapanagioti, 2005). Lower pressures also increase the surface area of charge (Hanaoka et al., 2012).

\subsection{Higher Heating Value (HHV)}

Table 4 displays the higher heating values for the various size fractions of the B1 and B2 ash samples. Heating values within each size class were relatively similar between the two ash samples. A range of approximately $5-25$ $\mathrm{MJ} / \mathrm{kg}$ was obtained for both samples. As the particle size fraction increased, the heating value of the fraction also increased. A slight decrease in the heating value was observed when moving from $850 \mu \mathrm{m}$ to $2000 \mu \mathrm{m}$ for both B1 and B2. The obtained HHVs suggest that the waste being disposed of has good energy potential and is comparable to some forms of biomass used in energy production processes (Liao, Wu, Yanyongjie, \& Huang, 2004).

Table 4. Higher heating value of boiler bottom ash samples separated within particle fractions

\begin{tabular}{ccc}
\hline Particle size $(\mu \mathrm{m})$ & $\mathrm{B} 1 \mathrm{MJ} / \mathrm{kg}$ & $\mathrm{B} 2 \mathrm{MJ} / \mathrm{kg}$ \\
\hline$<150$ & 7.02 & 8.89 \\
150 & 5.58 & 6.86 \\
250 & 7.40 & 10.40 \\
425 & 15.77 & 19.33 \\
850 & 22.96 & 24.56 \\
2000 & 20.83 & 23.54 \\
AR & 10.77 & 14.42 \\
\hline
\end{tabular}

All results are on a dry weight basis.

\subsection{Bulk Density}

The bulk density was calculated for each fraction and is represented as a function of particle size in Figure 5. B2 has lower bulk densities in all fractions. The as-received samples of B1 and B2 were 244 and $172 \mathrm{~kg} / \mathrm{m}^{3}$ respectively. For both $\mathrm{B} 1$ and $\mathrm{B} 2$, fractions $425 \mu \mathrm{m}$ and higher had significantly lower bulk densities than fractions $250 \mu \mathrm{m}$ and below. B1 fractions $425 \mu \mathrm{m}$ and higher had a bulk density range of $\sim 100-150 \mathrm{~kg} / \mathrm{m}^{3}$. Bulk density was $\sim 50 \%$ less for fractions $250 \mu \mathrm{m}$ and lower. For B2, bulk density was also $50 \%$ less for fractions $250 \mu \mathrm{m}$ and lower compared to fractions $425 \mu \mathrm{m}$ and higher.

The bulk densities were lower with samples of higher FC contents. Figure 6 shows the correlation of bulk density with percent $\mathrm{FC}$ within the various particle fractions. A linear relationship is established and shown in Equation 2. While the value of $R^{2}$ is 0.8692 , the graph shows a significant reduction in bulk densities of fractions with higher FC contents. If the carbon is reduced or eliminated in ash, the bulk density increases. This may be important in the transportation and storage of ash. With increasing bulk densities, greater amounts of ash could be transported from combustion plants to landfills. 


$$
\rho_{B}=-4.9579 \mathrm{FC}+406.73 \quad \mathrm{R}^{2} 0.8692
$$

$\rho_{B}$ represents Bulk density.

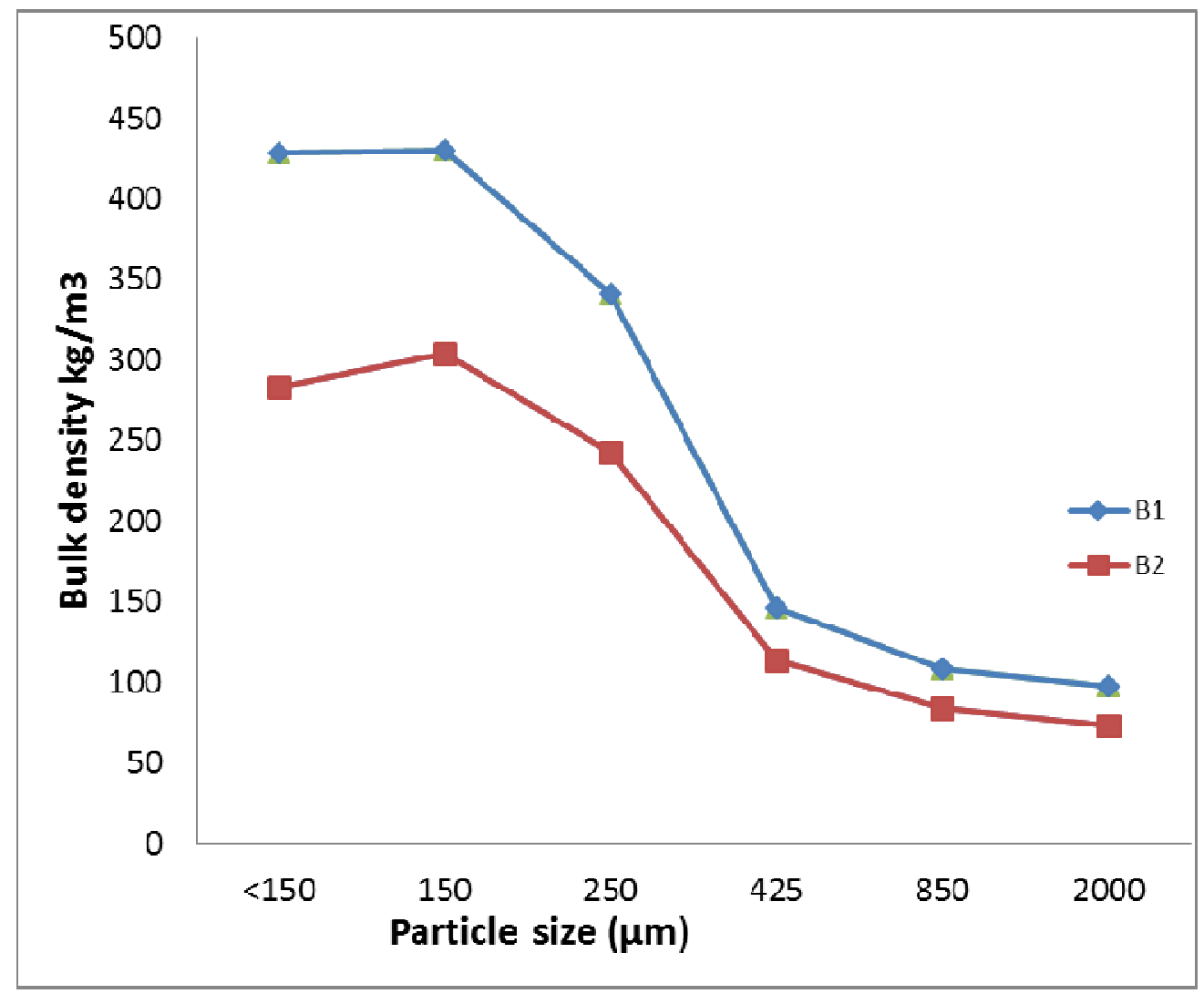

Figure 5. Bulk density variation with particle size $(\mu \mathrm{m})$ for boiler ash

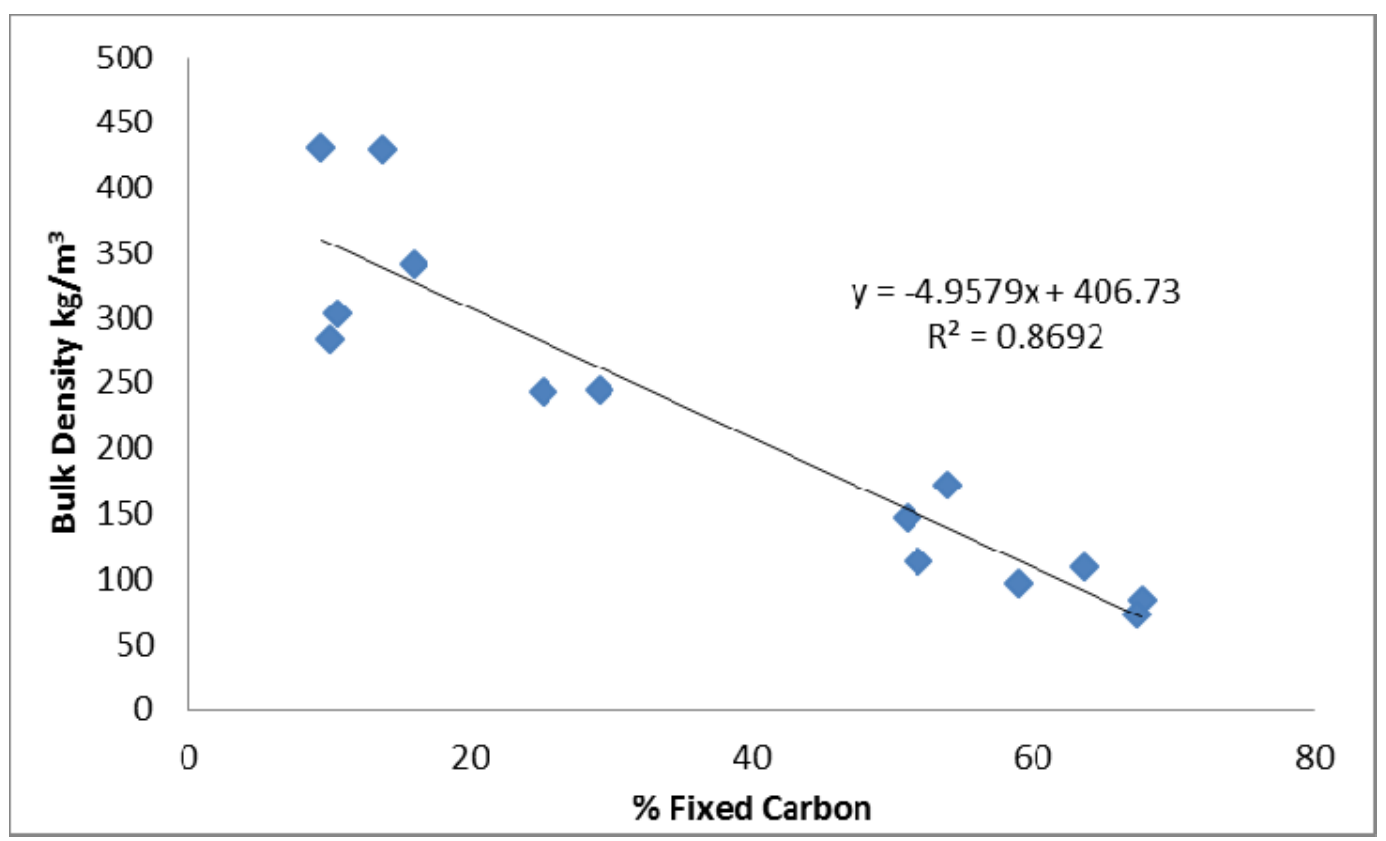

Figure 6. Bulk density versus percent fixed carbon for boiler ash 


\section{Summary of Results}

Table 5 summarizes some of the main results by reporting data obtained for the as-received fractions, combined fractions $\geq 425 \mu \mathrm{m}$ and combined fractions $<425 \mu \mathrm{m}$ for B1 and B2. When samples are collected from fractions $\geq$ $425 \mu \mathrm{m}$, the energy density can be increased by approximately $50 \%$ and $64 \%$ for B1 and B2 respectively when compared to the AR for both samples. In addition, the majority of the energy content is in the larger fraction $(\geq$ $425), 64 \%$ for $\mathrm{B} 1$ and $78 \%$ for $\mathrm{B} 2$. On a mass basis, less than half of the ash is in the larger fractions $(\geq 425)$. The bulk density analysis shows that the low carbon fractions of ash have four times the bulk density, compared to the high carbon fractions. This suggests a good opportunity for volume reduction. By reburning the larger size fraction, ash volumes can be decreased by over a half, while recovering more than two-thirds of the energy present in the as-received sample.

Table 5. Properties of boiler bottom ash of major ash fractions, based on $100 \mathrm{~kg}$ sample

\begin{tabular}{lcccccc}
\hline Parameter & $\mathrm{B} 1 \mathrm{AR}$ & $\mathrm{B} 1 \geq 425 \mu \mathrm{m}$ & $\mathrm{B} 1<425 \mu \mathrm{m}$ & $\mathrm{B} 2 \mathrm{AR}$ & $\mathrm{B} 2 \geq 425 \mu \mathrm{m}$ & $\mathrm{B} 2<425 \mu \mathrm{m}$ \\
\hline Mass $(\mathrm{kg})$ & 100.0 & 37.2 & 62.8 & 100.0 & 60.0 & 40.0 \\
Energy density $(\mathrm{MJ} / \mathrm{kg})$ & 10.8 & 20.0 & 6.7 & 14.4 & 22.4 & 9.7 \\
Energy content (GJ) & 1.08 & 0.74 & 0.42 & 1.44 & 1.34 & 0.39 \\
FC (\%) & 29.3 & 58.3 & 13.2 & 54.0 & 61.6 & 21.5 \\
Ash $(\mathrm{kg})$ & 54.8 & 9.7 & 42.8 & 30.2 & 14.8 & 24.4 \\
Bulk density $\left(\mathrm{kg} / \mathrm{m}^{3}\right)$ & 244.0 & 106.6 & 448.3 & 172.0 & 81.5 & 385.3 \\
Volume $\left(\mathrm{m}^{3}\right)$ & 0.41 & 0.35 & 0.14 & 0.58 & 0.74 & 0.10 \\
\hline
\end{tabular}

Bulk density calculated from Equation 2.

\section{Conclusions}

The boiler ash studied shows variability in carbon contents that may be a result of variations in retention time in the reactor, incomplete combustion, temperature variations and fluctuations and variations in moisture content. However, unique to both ash samples is a high carbon content in the larger size fractions, specifically for the fractions $\geq 425 \mu \mathrm{m}$. Separating and re-using particle sizes $425 \mu \mathrm{m}$ and higher would recover over $50 \%$ of the unburnt carbon that is present in this bottom ash. Sieve fractionation may allow for easy accessing of the carbon and may present itself as a cost effective pre-treatment method for reburning high carbon ash, in order to obtain the highest energy components. The reintroduction of ash in the combustion system may present challenges due to problems related to corrosion, scouring and fouling as experienced with the fixed bed boiler that produces this high carbon ash. Thermogravimetric analysis shows that this high carbon ash may be combusted and displays thermal phases similar to the combustion of lignocellulosic biomass. The highest rate of mass loss was $1.3843 \mathrm{mg} / \mathrm{min}$ for fractions $\geq 425 \mu \mathrm{m}$. This occurs at a lower peak temperature when compared to the other samples, resulting in lower ignition temperatures. There was no significant difference in the burn-out time for all 3 samples. The high surface area of the char particles could increase combustion or gasification reactivity rates, since a large surface area is available for oxidation. A linear correlation was identified between the FC and bulk density, where samples with higher concentrations of fixed carbon have lower bulk densities.

In an effort to ensure environmental sustainability and sustainable use of our biomass resources, efficient use must be realized. The use of woody biomass in bioenergy process must be such that all possible energy is extracted. It is preferred that bioenergy processes are able to so. However, should that be not possible due to system limitations or fuel type etc, other options must be employed in conjunction with existing technologies to ensure maximum use of the resource. Finally, the need for an in-depth analysis of the inorganic distribution within fractions of bottom ash should also be investigated for possible environmental and technical utilization. For example, there are likely to be similarities in the properties of ash and biochar. Biochar may have beneficial soil applications, for example biochar has been suggested to enhance seedling growth (Robertson, Rutherford, Lopez-Gutierrez, \& Massicotte, 2012; Knapp \& Insam, 2011). Perhaps high carbon ash could also have similar results for soil applications.

\section{Acknowledgments}

We would like to thank the following organizations for their support in conducting this research Canfor Pulp Mill and the University of Northern British Columbia Central Equipment Laboratory. Also, we acknowledge funding 
support from Natural Science and Engineering Research Council (NSERC) and Canfor Pulp Limited Partnership (CPLP).

\section{References}

Batra, V., Urbonaite, S., \& Svensson, G. (2008). Characterization of unburned carbon in bagasse fly ash. Fuel, 87, 2972-2976. http://dx.doi.org/10.1016/j.fuel.2008.04.010

Cetin, E., Moghtaderi, B., Gupta, R., \& Well, T. (2004). Influence of pyrolysis conditions on the structure and gasification reactivity of biomass chars. Fuel, 2004, 2139-2150. http://dx.doi.org/10.1016/j.fuel.2004.05.008

Demirbas, A. (2005). Potential applications of renewable energy sources, biomass combustion problems in boiler power systems and combustion related environmental issues. Progress in energy combustion science, 31, 171-192. http://dx.doi.org/10.1016/j.pecs.2005.02.002

Di Blasi, C. (2009). Combustion and gasification rates of lignocellulosic chars. Energy Combustion Science, 35 , 121-140. http://dx.doi.org/10.1016/j.pecs.2008.08.001

Dimitrakopoulous, A. (2001). Thermogravimetric analysis of Mediterranean plant species. Journal of Analytical and Applied Science, 60, 123-130.

Duan, L., Liu, D., Chen, X., \& Zhao, C. (2012). Fly ash recirculation by bottom feeding on aa circulating fluidized bed boiler co-burning coal sludge and coal. Applied Energy, 95, 295-299. http://dx.doi.org/10.1016/j.apenergy.2012.02.063

Elder, T., Kush, J., \& Hermann, S. (2011). Thermogravimetric analysis of forest understory grasses. Thermochimica Acta, 512, 170-1771. http://dx.doi.org/10.1016/j.tca.2010.10.001

Emilsson, S. (2006). International handbook. From extraction of forest fuels to ash recycling. Jonkoping: Swedish Foresty Agency.

Gomez-Barea, A., Vilches, L., Campoy, M., \& Fernandez-Pereira, C. (2009). Plant optimization and ash recycling in fluidised waste gasification. Chemical Engineering Journal, 146, 227-236. http://dx.doi.org/10.1016/j.cej.2008.05.039

Hanaoka, T., Sakanishi, K., \& Okumura, Y. (2012). The effect of N2/CO2/O2 content and pressure on charcateristics and $\mathrm{CO} 2$ gasification behaviour of biomass-derived char. Fuel Processing Technology, 104, 287-294. http://dx.doi.org/10.1016/j.fuproc.2012.05.024

Herrman, T., \& Baker, S. (2002). Evaluating particle size. Kansas: Kansas State University Agricultural Experiment Station and Cooperative Extension Service.

Idris, S., Rahman, N., \& Ismail, K. (2012). Combustion characteristics of Malaysian oil palm biomass, sub-bituminous coal and their respective blends via thermogravimetric analysis (TGA). Bioresource Technology, 123, 581-591. http://dx.doi.org/10.1016/j.biortech.2012.07.065

James, G., Sabatini, D., Chiou, C., Rutherford, D., Scott, A., \& Karapanagioti, H. (2005). Evaluating phenanthrene sorption on various wood chars. Water Research, 39(4), 549-558. http://dx.doi.org/10.1016/j.watres.2004.10.015

Khan, A., Jong, W., Jansens, P., \& Spliethoff, H. (2009). Biomass combustion in fluidized bed boilers: potential problems and remidies. Fuel processing technology, 90, 21-50. http://dx.doi.org/10.1016/j.fuproc.2008.07.012

Knapp, B., \& Insam, H. (2011). Recycling of biomass ashes: current technologies and future research needs. In I. H. Knapp B, Recycling of biomass ashes. Heidelberg: Springer. http://dx.doi.org/10.1007/978-3-642-19354-5_1

Liao, C., Wu, C., \& Yan, Y. (2007). The characteristics of inorganic elements in ashes from a 1 MW CFB bimass gasification power generation plant. Fuel Processing Technology, 88, 149-156. http://dx.doi.org/10.1016/j.fuproc.2005.06.008

Liao, C., Wu, C., Yanyongjie, \& Huang, H. (2004). Chemical elemental characteristics of biomass fuels in China. Biomass and Bioenergy, 27, 119-130. http://dx.doi.org/10.1016/j.biombioe.2004.01.002

Link, S., Arvelakis, S., Hupa, M., Yrjas, P., Kulaots, I., \& Paist, A. (2010). Reactivities of the biomass chars originating from reed, douglas fir and pine. Energy and Fuels, 24, 6533-6539. http://dx.doi.org/10.1021/ef100926v 
Miguel, G., Dominguez, M., Hemandez, M., \& Sanz-Perez, F. (2012). Characterization and potential applications of solid particles produced at a biomass gasification plant. Biomass and Bioenergy, 47, 134-144. http://dx.doi.org/10.1016/j.biombioe.2012.09.049

Miranda, T., Esteban, A., Rojas, S., Montero, I., \& Ruiz, A. (2008). Combustion analysis of ifferent olive residues. International Journal of Molecular Science, 9, 512-525. http://dx.doi.org/10.3390/ijms9040512

Moulijn, J., \& Kapteijn, F. (1995). Towards a unified theory of reactions of carbon with oxygen-containing molecules. Carbon, 8, 1155-1165. http://dx.doi.org/10.1016/0008-6223(95)00070-T

Obernberger, I., \& Supancic, K. (2009). Possibillities of ash utilisation from biomass combustion plants. Proceedings of the 17th European Biomass conference \& Exhibition. Hamburg: ETA Renewable Energies.

Pels, J., de Nie, D., \& Kiel, J. (n.d.). Improvement of the economics of biomass/waste gasification by higher carbon conversion and advanced ash management. Retrieved October 20, 2012, from http://www.ecn.nl/docs/library/report/2006/c06038.pdf

Picco, D. (2010). Technical assistance for the development and improvement of technologies, methodologies and tools for enhanced use of agricultural biomass residues. Gorizia.

Quaak, P., Knoef, H., \& Stassen, H. (1999). Energy from biomass. A review of combustion and gasification technologies. Washington, D.C.: World Bank Technical Paper; 422. Energy series.

Robertson, S., Rutherford, M., Lopez-Gutierrez, J., \& Massicotte, H. (2012). Biochar enhances seedling growth and alters root symbioses and properties of sub-boreal forest soils. Canadian Journal of Soil Science, 92, 329-340. http://dx.doi.org/10.4141/cjss2011-066

Ryu, C., Yang, Y., Khor, A., Yates, N., Sharifi, V., \& Swithenbank, J. (2006). Effect of fuel properties on biomass combbustion: Part 1. Experiments - fuel type, equivalence ration and particle size. Fuel, 85, 1039-1046. http://dx.doi.org/10.1016/j.fuel.2005.09.019

Saidur, R., Abdelaziz, E., Demirbas, A., Hossain, M., \& Mekhilef, S. (2011). A review on biomass as a fuel for boilers. Renewable and Sustainable Energy Reviews, 15, 2262-2289. http://dx.doi.org/10.1016/j.rser.2011.02.015

Sarenbo, S. (2009). Wood ash dilemma-reduced quality due to poor combustrion performance. Biomass and Bioenergy, 33, 1212-1220. http://dx.doi.org/10.1016/j.biombioe.2009.05.007

Van Loo, S., \& Kopejan, J. (2008). The handbook of biomass combustion and co-firing. Earthscan publications.

Warnecke, R. (2000). Gasification of biomass: comparison of fixed bed and fluidized bed gasifier. Biomass and Bioenergy, 18, 489-497. http://dx.doi.org/10.1016/S0961-9534(00)00009-X

Zhang, H., Zhao, Y., \& Jingyu, Q. (2010). Termal characterization of fly ash from municipal solid waste incinerator (MSWI) in Shanghai. Process Safety and Environmental Protection, 88, 269-275. http://dx.doi.org/10.1016/j.psep.2010.03.004

\section{Copyrights}

Copyright for this article is retained by the author(s), with first publication rights granted to the journal.

This is an open-access article distributed under the terms and conditions of the Creative Commons Attribution license (http://creativecommons.org/licenses/by/3.0/). 